\title{
Herpetological Journal ful PAarer Befts \\ How did the toad get over the sea to Skye? Tracing the colonisation of Scottish inshore islands by common toads (Bufo bufo)
}

\author{
David O'Brien ${ }^{1,2}$, Jeanette Hall ${ }^{2}$, Katie O’Brien ${ }^{3}$, Donal Smith ${ }^{1}$, Stewart Angus², Rohan Vishwas \\ Joglekar ${ }^{1} \&$ Robert Jehle ${ }^{1}$
}

\footnotetext{
1. University of Salford, School of Science, Engineering and Environment, Salford M5 4WT, UK

2. NatureScot (Scottish Natural Heritage), Great Glen House, Leachkin Road, Inverness IV3 8NW, UK

3. Highland Amphibian and Reptile Project, c/o Woodlands, Brae of Kinkell, Dingwall, IV7 8HZ, UK
}

\begin{abstract}
Processes of island colonisation have long been of interest to biologists. Colonisation events themselves are rarely observed, but the processes involved may be inferred using genetic approaches. We investigated possible means of island colonisation by common toads (Bufo bufo) in western Scotland (the Isle of Skye and five neighbouring small islands), using evidence derived from nuclear microsatellites and mitochondrial $(\mathrm{mt}) \mathrm{DNA}$. Levels of microsatellite allelic richness for populations on Skye were high and comparable to adjacent mainland populations, but lower for populations on small islands. Pairwise measures of genetic distances between populations and a clustering algorithm were both suggestive of frequent gene flow between Skye and the mainland. For small islands the levels of genetic differentiation were higher, implying stronger isolation and no evidence for inbreeding. The distribution of mtDNA haplotypes broadly mirrored the genetic structure revealed by microsatellites. Reconciled with existing palaeoclimatological evidence, since the last glaciation, our findings rule out the possibility that the $B$. bufo populations stem from glacial refugia, or that recent anthropogenic transfer of toads is responsible for their current distribution. The most parsimonious explanation of our data is that the studied inshore islands have been repeatedly colonised via rafting from the mainland or neighbouring islands. This may give us insights into the processes likely to take place when ice sheets retreat poleward as a result of climate change. It also has implications for the colonisation of both native and invasive non-native species, and hence the biosecurity of island refugia.
\end{abstract}

Keywords: Island biogeography, glaciation, amphibians, rafting

\section{INTRODUCTION}

s attin sland populations of widespread species have long attracted the attention of natural scientists (e.g. Wallace, 1880; Whittaker \& Fernández-Palacios, 2007). Populations on islands are also of interest to geneticists, due to restrictions on gene flow and the influence of founder effects which can both impact on population viability (Frankham, 1997; Reed \& Frankham, 2003). Modes of island colonisation and persistence are further of relevance for studies into how species might adapt to future rapid environmental change (Courchamp et al., 2014).

As one of the most severely threatened groups of those whose status has been assessed (IPBES, 2019), amphibians are a global conservation priority. Amphibians are also suitable subjects for island biogeographical studies, as they have limited powers of dispersal compared to flying animals such as birds, insects and bats, or organisms that drift by wind or zoochory (Cushman, 2006; Allentoft \& O'Brien, 2010). Their low to moderate salinity tolerance (reviewed in Hopkins \& Brodie, 2015) further implies difficulty particularly when colonising oceanic islands, as suggested by early authors including Darwin (1859, p. 393). For example, archipelagos such as the Canaries, Galapagos and Mauritius are occupied by reptiles, but do not harbour native amphibians. Amphibians have, however, colonised other islands by both anthropogenic and natural means. Human introduction may be accidental (Kuraishi, Matsui \& Ota, 2009) or deliberate (e.g. Shine, 2018). In some cases, amphibians arrived naturally before islands were cut off due to sea level rise (e.g. Wang et al., 2014), and in others they colonised islands after their formation. Natural colonisation of islands is assumed to take place for example by rafting upon floating vegetation or debris (Vences et al., 2003; Measey et al., 2007; reviewed in Marin da Fonte et al., 2019; see also Schiesari et al., 2003 for the frequent occurrence of rafting by amphibians in large tropical river basins). In inshore situations, dispersal by swimming could also be assisted by conditions of low-salinity, for example when a lack of wind allows a layer of less dense 
Table 1. Genetic variability parameters for 11 Bufo bufo populations characterised at 8 microsatellite loci.

\begin{tabular}{lccccccccc}
\hline \multicolumn{1}{c}{ Location } & Site & N & A/L & AR & Ho & He & F $_{\text {Is }}$ & ML & PA \\
\hline $\begin{array}{l}\text { Loch lain Oig, Kyle of Lochalsh, } \\
\text { mainland }\end{array}$ & MAK & 10 & 5.38 & 3.73 & 0.54 & 0.65 & 0.18 & 0 & 7 \\
Toscaig, nr Applecross, mainland & MAT & 10 & 4.50 & 3.14 & 0.51 & 0.51 & 0.00 & 0 & 2 \\
Lochan Dubh, Broadford, Skye & SKB & 11 & 3.88 & 3.33 & 0.36 & 0.41 & 0.13 & 0 & 2 \\
Loch a Mhuilinn, Portree, Skye & SKP & 20 & 4.25 & 2.73 & 0.49 & 0.51 & 0.03 & 0 & 2 \\
Pabay & PAB & 19 & 1.63 & 1.57 & 0.26 & 0.20 & -0.27 & 4 & 0 \\
Loch Beag, Raasay & RAB & 9 & 3.38 & 2.72 & 0.49 & 0.50 & 0.027 & 1 & 1 \\
Oskaig, Raasay & RAO & 10 & 4.00 & 2.86 & 0.45 & 0.47 & 0.053 & 1 & 2 \\
Loch na h lolaire, Rona & ROI & 11 & 3.25 & 2.49 & 0.34 & 0.39 & 0.12 & 0 & 1 \\
Township reservoir, Rona & ROT & 13 & 2.88 & 2.33 & 0.37 & 0.36 & 0.00 & 3 & 1 \\
East of Loch Dubh, Scalpay & SCD & 10 & 4.50 & 3.30 & 0.56 & 0.58 & 0.024 & 0 & 3 \\
Loch nan Leac, Crowlin & CRO & 31 & 4.73 & 2.90 & 0.56 & 0.61 & 0.12 & 0 & 6 \\
\hline
\end{tabular}

n, number of individuals sampled; A/L, mean number of alleles per locus; AR, allelic richness; Ho, observed heterozygosity; He, expected heterozygosity; ML, number of monomorphic loci; PA, number of private alleles.

freshwater from river outflow to lie on top of sea water (discussed in Seppä \& Laurila, 1999). Other proposed mechanisms for dispersal of amphibians include tornados (Elsom, 1988) and transport of eggs by waterbirds (for an example on fish see Lovas-Kiss et al., 2020), although documented evidence is largely lacking.

Glaciation has been a principle geomorphological and biogeographic shaper of lands beyond $45^{\circ}$ latitude. In Europe, this has led to a pattern of biodiversity richness in central and southern Europe, with reduced diversity linked to post-glacial recolonisation in the north (e.g. Hewitt, 2000). The glacial history of Scotland is similar to that of other European high latitudes, and its fauna is well-studied. Interestingly, the melting of the main glaciers at the end of the last glacial c. 15,000 years before present (ybp) (Mayle et al., 1F999) in Scotland was also followed by a cold period between c. 12,900 and 11,700 ybp, which led to the temporary re-forming of glaciers ranging from Loch Lomond in the central belt northward to Torridon in the western Highlands (the Younger Dryas or Loch Lomond Stadial; Bradwell et al., 2008; Ballantyne, 2019).

The western Scottish Highlands are characterised by low human population density and low levels of intensive agriculture, and are home to three species of amphibians (the common toad B. bufo, the common frog Rana temporaria and the palmate newt Lissotriton helveticus). These species are recorded regularly not only on the mainland but also on a range of inshore islands (Mclnerny \& Minting, 2016; Fiegna et al., 2017; NBN, 2019), which were already separated from the mainland when Britain was still connected to mainland Europe up to $8000 \mathrm{ybp}$ (Lambeck, 1995; Ballantyne, 2019). In the present study we focus on $B$. bufo, a widespread species which has previously served for population genetic investigations in northern European archipelagos (Seppä \& Laurila, 1999; Roth \& Jehle, 2016). We employ information derived from nuclear and mitochondrial DNA markers to (i) document spatial patterns of genetic variation across the Isle of Skye, adjacent mainland and small islands of the Inner Sound, and (ii) use these data to infer possible means of island colonisation. More specifically, we reconcile the obtained genetic data with existing evidence from palaeoclimatology, and ask whether the islands under study became colonised prior to the Loch Lomond Stadial, for example via land bridges, or after this period when meltwater would have temporarily reduced the salinity of inshore waters. Alternatively, B. bufo may also have reached these islands more recently through human introductions or natural means. Our study complements similar local investigations for example on small mammals (White \& Searle, 2007; 2008), and provides information on the origin of the westernmost natural populations of a widespread European anuran.

\section{MATERIALS \& METHODS}

\section{Field sampling}

This study took place in the western Scottish Highlands (UK), and encompassed two waterbodies on the Isle of Skye $\left(1656 \mathrm{~km}^{2}\right.$ in area, connected to the mainland by a ca. $500 \mathrm{~m}$ long bridge erected in 1995), two waterbodies on the adjacent mainland, and seven waterbodies across all islands with standing freshwater in the Inner Sound (Rona and Raasay, two waterbodies each; Scalpay, Pabay and Crowlin, one waterbody each; see Table 1 and Figure 1). Crowlin is seldom visited and like Pabay has no permanent human population, while Scalpay and Rona each have fewer than five inhabitants. The isolated islands range in size from $1.3 \mathrm{~km}^{2}$ (Pabay) to $53.4 \mathrm{~km}^{2}$ (Raasay) and have been separated by sea since the last period of glacial activity in the area ended approximately 9500 years BP (Lambeck, 1995), although it is possible to cross from Skye to Scalpay during extreme low tides. A total of 157 samples were collected between 2013 and 2015 , as eggs derived from ten spawn strings at each site, or tadpoles taken at least $10 \mathrm{~m}$ apart to reduce the risk of sampling siblings ( $n=9-31$ individuals per population, Table 1). Samples were stored in $1.5 \mathrm{ml}$ Eppendorf tubes filled with absolute ethanol. 


\section{Genetic analyses}

DNA was extracted from whole eggs or tadpole tail tissue using the Qiagen DNEasy Blood and Tissue extraction kit (Qiagen, UK) following the manufacturer's protocol. Concentration of extracted DNA was quantified using a NanoDrop Lite spectrophotometer (Thermo Fisher Scientific, USA) and standardised to approximately 10 $\mathrm{ng} / \mu \mathrm{l}$.

For analyses of mitochondrial DNA, a 722bp long fragmentofthecytbregionwasamplifiedforthreeindividuals from all 11 population using PCR primers described in Recuero et al. (2012; F: ATCTACCTTCACATCGGACGAG, R: AGTTTRTTTTCTGTGAGTCC), and a $10 \mu \mathrm{I}$ PCR reaction mix containing 10-50 ng DNA, $5 \mathrm{pmol}$ ( $5 \mathrm{mmol} / \mathrm{L}$ ) of each primer, $0.15 \mathrm{mmol} / \mathrm{L}$ of each dNTP, $1.5 \mathrm{mmol} / \mathrm{L}$ $\mathrm{MgCl}$, and 0.5-1.0 $\mathrm{U}$ Taq polymerase (GoTaq) in the manufacturer's buffer. The PCR reaction was carried out at the following amplification conditions: $2 \mathrm{~min}$ at $96{ }^{\circ} \mathrm{C}$, followed by 37 cycles of $30 \mathrm{~s}$ at $94{ }^{\circ} \mathrm{C}, 45 \mathrm{~s}$ annealing at $53^{\circ} \mathrm{C}$ and $1 \mathrm{~min} 30 \mathrm{~s}$ at $72{ }^{\circ} \mathrm{C}$, and a final 5 mins at $72{ }^{\circ} \mathrm{C}$. In total, 154 samples from all but one population (SCM) werealsogenotypedateightexisting $B$. bufo microsatellite loci (Bbuf11, Bbuf15, Bbuf24, Bbuf39, Bbuf46, Bbuf54, Bbuf62, and Bbuf65; Brede et al. 2001). PCRs contained 10-50 ng DNA, $5 \mathrm{pmol}$ ( $5 \mathrm{mmol} / \mathrm{L}$ ) of each primer, 0.15 $\mathrm{mmol} / \mathrm{L}$ of each dNTP, $1.5 \mathrm{mmol} / \mathrm{L} \mathrm{MgCl} 2$, and 0.5-1.0 U Taq polymerase (Advanced Biotechnologies, Columbia, $M D$ ) in the manufacturer's buffer, at a total volume of $10 \mu \mathrm{l}$. The PCR profiles were $94^{\circ} \mathrm{C}$ for $2 \mathrm{~min}$, followed by 39 cycles of $94{ }^{\circ} \mathrm{C}$ for $30 \mathrm{~s}$, the primer-specific annealing temperatures as in Brede et al. (2001) for $30 \mathrm{~s}$, and 72 ${ }^{\circ} \mathrm{C}$ for $30 \mathrm{~s}$. We used PCR primer-specific annealing temperatures as described in Brede et al. (2001), with the exception of Bbuf11 which was found to yield more PCR product at an annealing temperature of $56{ }^{\circ} \mathrm{C}$. Primers were labelled with fluorochromes PCR products, and were separated by capillary electrophoresis using an $A B I$ 3130 Genetic Analyser (Applied Biosystems), and sized using Peak Scanner Software v1.0 (Applied Biosystems).

\section{Statistical analyses}

Haplotype sequences derived from the mtDNA analysis were aligned using Clustal W (Thompson et al., 1994) in BioEdit ver 7.1.3.0 (Hall, 1999). Obtained sequences were compared with existing data in GenBank, with haplotype designations following the terminology of Tuncay et al. (2018). To illustrate the population share across haplotypes, and to distinguish between ancestral and derived haplotypes, NETWORK 10 (Fluxus Technology Ltd., www.fluxus-engineering.com/sharenet.htm) was used to compile a median-joining (MJ) network. Due to the limited number of samples available for each population we refrained from detailed statistical analyses. For microsatellites, observed $\left(H_{o}\right)$ and expected $\left(H_{e}\right)$ heterozygosities, deviations from Hardy-Weinberg equilibrium and pairwise $F_{S T}$ values between populations were calculated using the software GENEPOP 4.4 (Rousset, 2008). Allelic richness values for each population were calculated using FSTAT (Goudet, 1995). Following Rousset (1997), a pattern of isolation by distance was evaluated using Mantel tests (10000 permutations) comparing linearised $F_{S T}$ values $F_{S T} /\left(1-F_{S T}\right)$ with log-transformed pairwise geographic distances carried out using the $R$ package VEGAN (Oksanen et al., 2018). A Kruskal-Wallis test was carried out in $R$ version 3.5.0 ( $R$ Core Team, 2018 ) to compare $F_{S T}$ values calculated for populations separated by sea and those separated by land. Spearman rank correlations between the mean of a population's $F_{S T}$ values and both its allelic richness and expected heterozygosity were also calculated using $R$. STRUCTURE 2.3.4 (Pritchard et al., 2000) was used to identify the most likely number of genetic clusters $(K)$ within the dataset. STRUCTURE uses a Bayesian iterative algorithm to assign the membership of each sample probabilities to a pre-defined number of clusters. Largely following Porras-Hurtado et al. (2013), 20 independent runs were performed for each value of $K$ from 1 to 13, with 200 000 Markov Chain Monte Carlo iterations after a burnin of 200,000 iterations. The best-supported value of $K$ was determined using $\Delta K$, related to the rate of change in log probability between successive $K$ values (Evanno et al., 2005), using STRUCTURE HARVESTER (Earl \& von Holdt, 2012). Replicates for each level of $K$ were aligned using CLUMPP 1.1.2 (Jakobsson \& Rosenberg, 2007) and graphical output was produced using DISTRUCT 1.1 (Rosenberg, 2004).

\section{RESULTS}

The mtDNA analysis revealed a total of five haplotypes (Fig. 1). H_9 (32\% of all individuals, present in six populations) is commonly reported in the western distribution of $B$. bufo, and has been previously found in the UK (Recuero et al., 2012; Arntzen et al., 2017); all other haplotypes have not previously been reported for B. bufo. The most frequent haplotype (H_62) represented $56 \%$ of individuals across nine populations, and differed from $\mathrm{H}_{-} 9$ by a single base substitution. Three further haplotypes were represented by one (H_65) or two (H_63 and H_64) individuals (Fig. 2). The new sequences have been deposited in Genbank (accession numbers: MZ318468 - MZ318490).

For microsatellites, the PCR success rate was $91 \%$. Mean number of alleles per locus ranged between 1.63 for an island population (PAB) and 5.38 for a mainland population (MAK). Both mainland populations and one Skye population (SKB) showed higher levels of allelic richness (3.14-3.73) than all but one island population ( $S C D$, on Scalpay which is connected to the Isle of Skye at low water spring tides (Admiralty Chart 2498, 2018). Four populations revealed monomorphic loci, all of which were situated on small islands (Table 1 ). $F_{S T}$ values for populations on the mainland and on the large Isle of Skye, or on the same small island ranged from -0.01 to 0.13 , whereas those between populations on the smaller islands ranged from 0.07 to 0.50 (Table 2), with highly significant differences between these two groups (Kruskal-Wallis test, $p<0.001$ ). The allelic richness of a population was strongly negatively associated with its degree of isolation (defined by the mean of the 


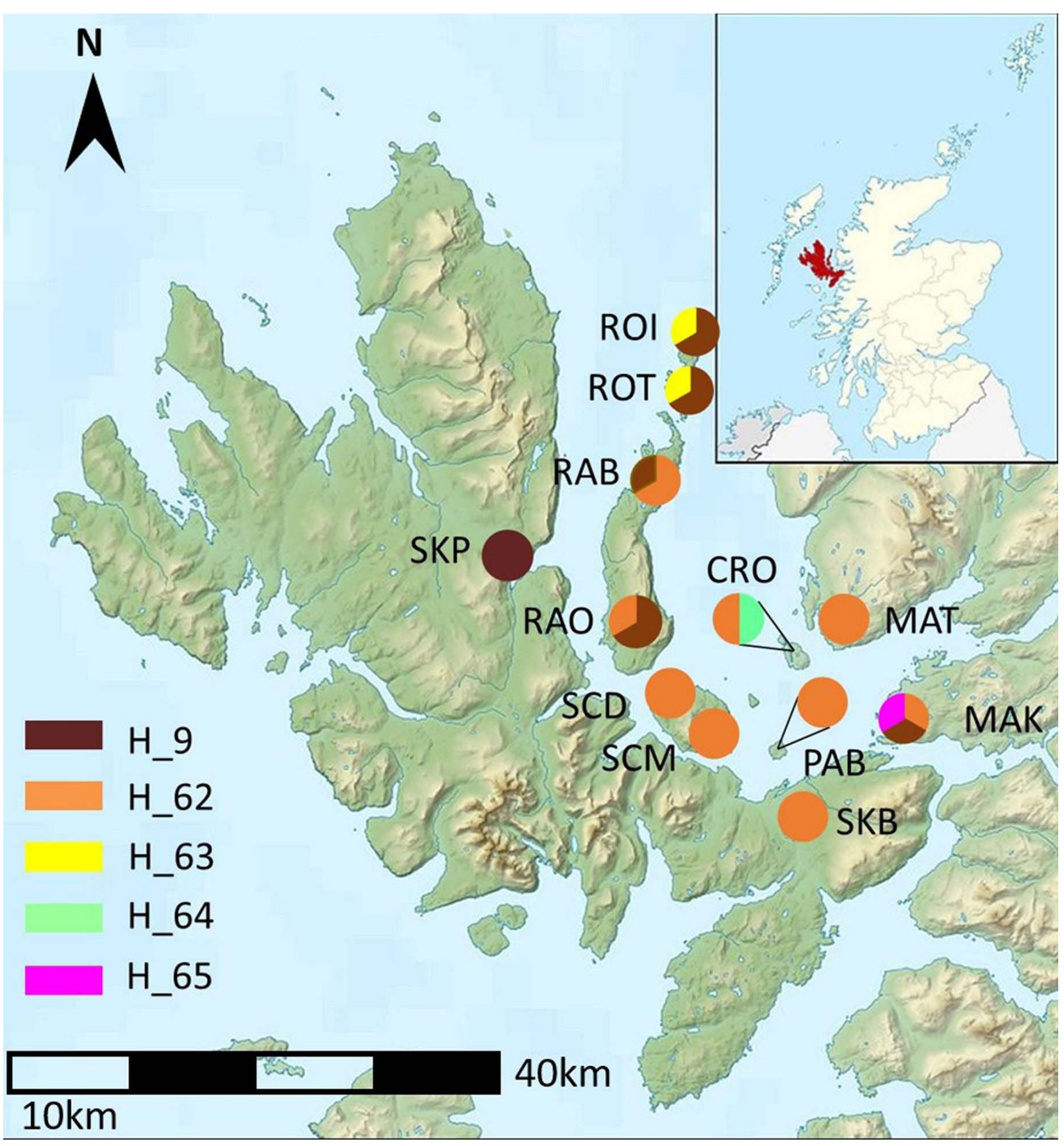

Figure 1. Locations of Bufo bufo breeding sites sampled and haplotype distribution. Inset shows position of study area in Scotland. See Table 1 for more detail of sampling sites. Contains Ordnance Survey data (C) Crown copyright and database right.

pairwise $F_{S T}$ values with all other populations; Spearman rank correlation coefficient $-0.84, p=0.001$ ). Similarly, expected mean heterozygosity showed a marginally significant tendency towards a negative correlation with mean $F_{S T}$ (Spearman rank correlation coefficient $-0.58, \mathrm{p}$ $=0.062$ ). A weak, but significant, isolation-by-distance effect was present (Mantel test, $r=0.23, p=0.04$ ).

The log probability of numbers of clusters according to the STRUCTURE analysis increased from $K=1$ through $K=7$, with a modal value of $\Delta K$ at $K=4$. The genetic clusters reflected their geographic context. All mainland and Skye populations as well as the populations on Raasay and Scalpay were predominantly assigned to a single cluster, whereas each of the remaining three small islands represented a distinct genetic unit (Fig. 3).

\section{DISCUSSION}

The present paper sought to combine new information drawn from DNA with existing geographic and palaeoclimatological evidence to infer the most likely colonisation history of inshore islands in the western Scottish Highlands by $B$. bufo. Below, we first discuss the spatial patterns of genetic variation. We then consider possible mechanisms of island colonisation which could have led to the observed island distribution: deliberate 
Table 2. Pairwise $F_{\mathrm{ST}}$ values for 11 Bufo bufo populations. Continuous box borders denote populations separated by land, the broken border denotes populations separated by land and the Skye Bridge, and the remaining values show populations separated by sea.

\begin{tabular}{|c|c|c|c|c|c|c|c|c|c|c|c|}
\hline & & MAK & MAT & SKB & SKP & PAB & RAB & RAO & ROI & ROT & SCD \\
\hline MAT & & 0.04 & & & & & & & & & \\
\hline SKB & 1 & -0.01 & $\overline{0.05}$ & & & & & & & & \\
\hline SKP & ᄂ & 0.10 & $\underline{0.13}$ & 0.06 & & & & & & & \\
\hline PAB & & 0.32 & 0.38 & 0.34 & 0.32 & & & & & & \\
\hline RAB & & 0.11 & 0.20 & 0.09 & 0.17 & 0.35 & & & & & \\
\hline RAO & & 0.15 & 0.30 & 0.18 & 0.23 & 0.37 & 0.07 & & & & \\
\hline ROI & & 0.24 & 0.27 & 0.21 & 0.28 & 0.49 & 0.29 & 0.32 & & & \\
\hline ROT & & 0.30 & 0.36 & 0.30 & 0.37 & 0.50 & 0.33 & 0.32 & 0.05 & & \\
\hline SCD & & 0.07 & 0.13 & 0.09 & 0.18 & 0.21 & 0.13 & 0.15 & 0.25 & 0.27 & \\
\hline CRO & & 0.13 & 0.22 & 0.11 & 0.20 & 0.40 & 0.17 & 0.24 & 0.28 & 0.32 & 0.20 \\
\hline
\end{tabular}

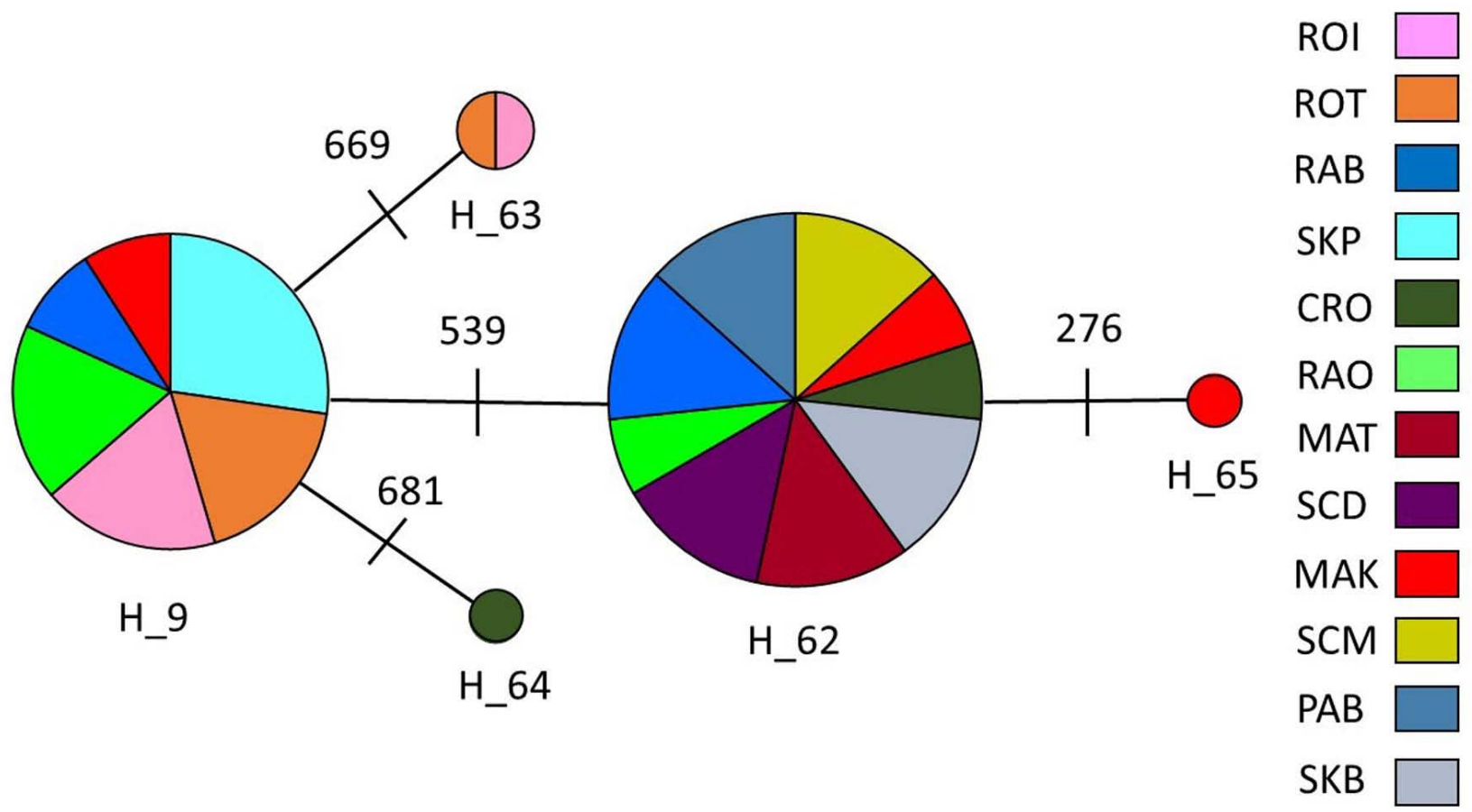

Figure 2. Median Joining Haplotype Network of B. bufo cytb sequences from the study area. Nucleotide positions of mutated sites are shown as numbers; shared haplotypes are divided into colours representing the populations shown in Figure 1.

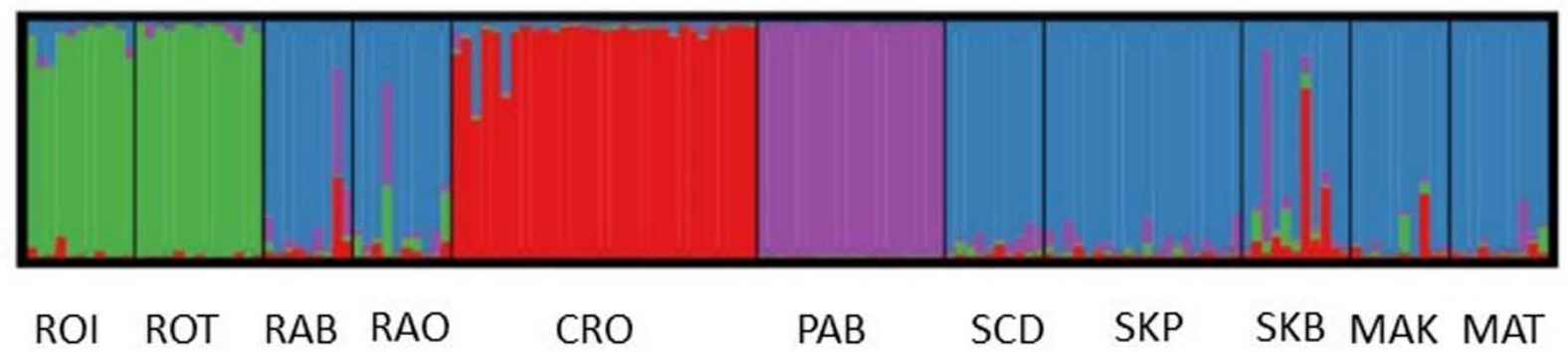

Figure 3. Bar plot showing assignment of all sampled individuals to the 4 genetic clusters determined by STRUCTURE. Each horizontal line denotes an individual, with the size of each colour bar corresponding to the probability of membership of each of four clusters. Three letter codes refer to breeding sites, as shown in Figure 1 and Table 1. 
or accidental human introduction, colonisation of islands before their isolation, colonisation of islands by swimming before salinification of the Inner Sound, and colonisation by rafting. Whilst not conclusively supporting a single mechanism, our findings strongly suggest that the last is most likely.

\section{Population genetic structure}

Previous studies of $B$. bufo populations on northern European inshore islands have revealed significant levels of differentiation between islands (Seppä \& Laurila, 1999; Roth \& Jehle, 2016), a finding which is mirrored in our study. We also revealed an overall concordance between the two genetic markers we employed. For example, the two populations on the island of Rona (ROI and ROT) showed unique mtDNA haplotype signatures combined with representing a distinct microsatellite-based cluster. This suggests that the colonisation did not take place through 'island hopping' after a single colonisation event from the mainland, but, for example, multiple times from different mainland sources. Haplotype (H_9) has previously been found in the UK as well as in central and northern Europe (Recuero et al., 2012; Arntzen et al., 2017). Its ancestral position in our study area is indeed confirmed by the haplotype network, which also illustrates that all other haplotypes are separated from each other by a single base substitution. Haplotypes which were previously unrecorded in other parts of the species' range) were also for example found on the western coast of Norway (Tuncay et al., 2018; see also Thörn et al., 2021 for multiple recolonisation routes of $B$. bufo in Scandinavia), and more extended sampling is required to assess their wider distribution and possible relevance for biogeographic patterns. It also needs to be borne in mind that, at a sample size of three individuals per population and with at least five haplotypes present in the area, our sampling regime does not allow us to fully capture the spatial distribution of existing diversity. Based on microsatellites, $F_{S T}$ values between populations of the Inner Sound islands are markedly higher than found in previous studies of $B$. bufo in study areas which are uninterrupted by seawater (Brede \& Beebee, 2004; Luquet et al., 2015); or for the closely related B. spinosus (Wilkinson et al., 2007; Martinez-Solano \& Gonzalez, 2008), suggesting their rather strong isolation. Levels of differentiation between the two populations on Skye and the two populations on the mainland were however markedly lower, suggesting recent gene flow and coinciding with data obtained for small mammals also on Skye (White \& Searle, 2008). That population on the nearby islands Raasay and Scalpay contained the same two mtDNA haplotypes and formed a single microsatellitebased cluster with Skye and the mainland suggests that Skye serves as a stepping stone for their colonisation. The distinctiveness of microsatellite genotypes of PAB on the small island of Pabay is paralleled by an excess of heterozygotes, likely reflecting that the local population consists of a very small number of individuals (no eggs or tadpoles were found in the single known available waterbody during later surveys, unpublished).
The degree of physical isolation of given islands from the mainland and the northward direction of prevailing currents paralleled the observed standing amounts of genetic diversity. Monomorphic loci were only found on smaller islands (four out of the seven populations), and are suggestive of genetic drift under a scenario of isolation. Possibly linked to island size, the overall level of genetic differentiation was higher than previously recorded for other populations of this species that were also separated by seawater (Seppä \& Laurila, 1999; Roth \& Jehle, 2016).

\section{Island colonisation}

Human introduction, both accidental and deliberate, are well documented for islands of western Scotland. For example, wood mice Apodemus sylvaticus on islands of the Outer Hebrides appear more closely related to populations from Scandinavia than to those from the Scottish mainland or Skye, possibly through accidental transport in Viking cargoes, although their parasites do not show the same pattern (Berry, 1979; Angus, 2001). The islands of the Inner Sound have been visited by boat since the days of the first settlers, and current settlement patterns or island sizes are rather uninformative for tracing releases (for example, the vole Microtus agrestis is common on the island of Uist but absent from the larger, more inhabited neighbouring island of Lewis and Harris; Angus, 1980).

Herpetofauna, including bufonids, are well known to be accidently transported though human activity (White \& Shine, 2009; Tingley et al., 2017). All of the islands have been used for rearing livestock, leading to opportunities for stowaways. However, interviews with a family of local graziers suggested that, for the example of Crowlin, there has been no transport of fodder in at least the last 100 years. Since prior to construction of roads and railways the main means of transport to the area was by boat, larger islands on the Outer Hebrides would be more likely to hold $B$. bufo than the relatively unimportant islands of the Inner Sound if accidental transport is common. However, there are no records of toads from the Outer Hebrides prior to the 21st century (NBN 2019), whereas the New Statistical Account (1845) already reported the "islands of the parish abound with them" in Kilmuir in the north of Skye. This suggests that accidental transport is an unlikely means of colonisation.

Intentional amphibian introductions have generally been of edible species (e.g. Lithobates catesbeanus to the Philippines; Pili et al., 2019), for pest control (e.g. Rhinella marina; Shine, 2018) and for ornamental purposes and the release of pets (e.g. Ichthyosaura alpestris to France, New Zealand and mainland Britain; Arntzen et al., 2016). It seems unlikely that $B$. bufo would have been deliberately introduced for the above reasons, although releases are known from similar habitats in Norway (Dolmen \& Seland, 2016). Deliberate small-scale introductions elsewhere in Scotland have been documented for the great crested newt Triturus cristatus, the smooth newt $L$. vulgaris and the alpine newt I. alpestris (Mclnerny \& Minting, 2016), in addition 
to extra-limital releases of $R$. temporaria and $L$. helveticus which served as demonstration animals from schools in the Outer Hebrides (Stewart Angus, unpublished data). Such small-scale introductions would however be reflected in the genetic make-up of populations (e.g. low allelic richness or lack of haplotype diversity, see Arntzen et al., 2010; Tingley et al., 2015), and would not explain the population on the uninhabited Crowlin Island.

Natural colonisation therefore seems the most likely explanation of the presence of toads on Skye and the Inner Sound. Toads may have colonised these islands for example via land bridges prior to the Loch Lomond Stadial and have persisted since, as has been argued for shrews (White \& Searle 2008). B. bufo reaches latitudes of $68^{\circ}$ and occurs within $1 \mathrm{~km}$ of glaciers elsewhere in Europe (Sillero et al., 2014). However, at the time of the Loch Lomond re-advance, ice sheets were present over much of Scotland (Ballantyne, 2019). While other amphibians can reproduce in waterbodies on permafrost (Salamandrella keyserlingii, Alfimov \& Berman, 2010), we have found no similar records for anurans such as $B$. bufo. Notwithstanding phylogeographic evidence from other taxa for persistence in glaciated areas (e.g. King et al., 2020; Taylor, 1983), we therefore consider the hypothesis of relict populations surviving during the Loch Lomond Stadial to be rather unlikely.

A further hypothesis is that $B$. bufo could have colonised Skye and surrounding islands following the Loch Lomond re-advance and related rising temperatures, but before the islands became cut off by salt water. The current salinity of Inner Sound is slightly lower than that of the open sea (34-34.5\%o salt c.f. $35 \%$ in the nearby Atlantic; Barne et al., 1997) but well above the tolerance level for B. bufo (Beebee, 1983). Due to isostatic uplift of islands offsetting eustatic sea level rises, the relative sea level in the region remained roughly the same over the last 9000 years (Shennan et al., 2000), meaning that the islands were not joined to the mainland. However, the waters of the largely landlocked Inner Sound would have been mainly composed of meltwater from retreating glaciers. Meltwater from surviving glaciers in the mountains would probably have been at its peak in spring, coinciding with amphibian movements and spawning, and the boreal toad Anaxyrus boreas has been recorded swimming in glacial runoff (Taylor, 1983). Salt tolerance in amphibians may not be as rare as previously assumed, with coastal populations showing strong evidence of increased saltwater tolerance (Hopkins \& Brodie, 2015; Albecker et al., 2021); indeed anecdotally $B$. bufo has been described swimming in the Baltic Sea at a salinity of 5-8\%o (Thulin \& Andrushaitis, 2003). Under a scenario of colonisation exclusively by swimming, each of the islands would however have become isolated broadly simultaneously by the increasing salinity, as a hypothesis leading to long-term isolation associated with significant genetic erosion (effective population sizes in $B$. bufo are low; Brede \& Beebee, 2004, Coles et al., 2019). This is however not reflected in our genetic data, which show that small islands such as Crowlin have substantial levels of genetic variation.
Although amphibians likely show lower propensity for colonisation by rafting than more desiccationresistant taxa such as reptiles or arthropods, this mode of dispersal appears possible across the relatively short inshore distances involved in this study (for a review see Marin da Fonte, 2019). The melting of glaciers is also associated with frequent spates, whereby sections of riverbank detach and float downstream and out to sea, along with biota they contain (washouts of pools adjacent to rivers, possibly containing amphibian spawn or larvae). Such processes might have been paralleled by 'rock slope failures' arising from seismic activity on shorelines associated with release from glacial loading (Ballantyne et al., 2014). The general occurrence of occasional rafting would leave a genetic signature in which islands with larger coasts and those closest to the mainland river outflows are characterised by the highest levels of genetic diversity due to repeated arrivals of new colonists.

We found clear evidence of strong isolation between small island and mainland populations, with the most northerly islands showing the lowest levels of allelic richness (with the exception of the very small population on Pabay), whereas genetic differentiation between Skye and the mainland was less pronounced. Skye is connected to the mainland by a ca. $500 \mathrm{~m}$ long bridge completed in 1995, although we do not assume that it is an important means of colonisation and gene flow for $B$. bufo (the highly mobile pine marten Martes martes have been able to colonise Skye over the bridge, but by 2010 were not known from further north than Broadford in the south of Skye; Cottis, 2011). Given the large B. bufo populations, their long documented history on the island and their wide spatial distribution on Skye before and after the bridge's construction (New Statistical Account, 1845; NBN, 2019), it seems highly unlikely that enough toads to affect population genetics could have crossed the bridge. Skye is also connected to Scalpay by land at extreme low tides (Admiralty Chart 2498, 2018), which likely explains the low $F_{S T}$ values between these sites. Occasional zoochory by birds would result in similar spatial genetic patterns but is generally deemed less likely, although birds have locally been found to carry snails (Evans, 1915) and might have led to colonisation of the nearby Uists by a further two molluscs species (Angus, 2001). Taken together, our evidence suggests that rafting is the most likely means of colonisation, and there is clearly an opportunity for future studies of amphibians and other low-mobility salt-intolerant taxa through systematic examination of rafts and debris.

The coasts of Scotland have much in common with other high latitude post-glacial marine-influenced areas such as Norway, Canada, Alaska, Chile and Southern New Zealand. The range of colonisation modes may differ in non-glacial settings, however. From a conservation perspective, our findings may offer some hope for unassisted range expansion of amphibians. The lack of evidence of inbreeding is particularly positive, and may be applicable for isolated mainland coastal populations as well as those on islands. On a more negative note, 
the ability of amphibians to cross seemingly impassable barriers means that island populations may not be safe from the spread of disease (e.g. chytrid) or non-native species (e.g. risk of colonisation of Maude Island New Zealand stronghold of Leiopelma hamiltoni, by invasive Litoria spp.).

\section{Ethical statement}

All aspects of fieldwork, including biosecurity, collection of specimens and handling of animals adhered to Scottish Natural Heritage's (the Scottish Government's statutory nature agency) guidelines.

\section{ACKNOWLEDGEMENTS}

We would like to thank Highland Biological Recording Group for subsidising much of the fieldwork, Babs McRitche and Benjamin Rome for assistance in the field, Peter Thompson for historical cultural and agricultural information, Ali Rennie and Fairlie Kirkpatrick Baird for comments on an early draft, and Nigel Smith and the team at Seaprobe Atlantis for logistical support. We would also like to thank the Editor and reviewers, Anita Malhotra, John Wilkinson and Stuart Graham, for their supportive comments. All aspects of fieldwork, including biosecurity, collection of specimens and handling of animals adhered to Scottish Natural Heritage's (the Scottish Government's statutory nature agency) guidelines.

\section{REFERENCES}

Admiralty Chart 2498 (2018). Inner Sound - Southern part. UK Hydrographic Office, Taunton.

Albecker, M.A., Stuckert, A.M.M., Balakrishnan, C.N. \& McCoy, M.W. (2021). Molecular mechanisms of local adaptation for salt-tolerance in a treefrog. Molecular Ecology, early online.

Alfimov, A.V. \& Berman, D.I. (2010). Reproduction of the Siberian salamander, Salamandrella keyserlingii (Amphibia, Caudata, Hynobiidae), in water bodies on permafrost in Northeastern Asia. Bulletin of the Russian Academy of Sciences 37, 807822.

Allentoft, M.E. \& O'Brien, J. (2010). Global amphibian declines, loss of genetic diversity and fitness: a review. Diversity 2, 47-71.

Angus, S. (1980). The status and ecology of voles Microtus agrestis (L.) in the Outer Hebrides. Hebridean Naturalist 4, 17-19.

Angus, S. (2001). The Outer Hebrides: Moor and Machair. Harris and Cambridge: White Horse Press.

Arntzen, J.W., Burke, T. \& Jehle, R. (2010). Estimating the propagule size of a cryptogenic crested newt population. Animal Conservation 13, 74-81.

Arntzen, J.W., King, T.M., Martínez-Solano, I. \& Wallis, G. P. (2016) Provenance of Ichthyosaura alpestris (Caudata: Salamandridae) introductions to France and New Zealand assessed by mitochondrial DNA analysis. The Herpetological Journal 26, 49-56.

Arntzen, J.W., de Vries, W., Canestrelli, D. \& Martínez-Solano, I. (2017). Hybrid zone formation and contrasting outcomes of secondary contact over transects in common toads. Molecular Ecology 26, 5663-5675.

Ballantyne, C.K., Sandeman, G.F., Stone, J.O. \& Wilson, P. (2014). Rock-slope failure following Late Pleistocene deglaciation on tectonically stable mountainous terrain. Quaternary Science Reviews 86, 144-157.

Ballantyne, C.K. (2019). After the ice: Lateglacial and Holocene landforms and landscape evolution in Scotland. Earth and Environmental Science Transactions of the Royal Society of Edinburgh 110, 133-171.

Barne, J.H., Robson, C.F., Kaznowska, S.S., Doody, J.P., Davidson, N.C. \& Buck, A.L., eds. (1997). Coasts and seas of the United Kingdom. Regions 15 and 16. North-west Scotland: The Western Isles and West Highland. Peterborough: JNCC

Beebee, T.J.C. (1983) The Natterjack Toad. Oxford: OUP.

Berry, R.J. (1979). The Outer Hebrides - where genes and geography meet. Proceedings of the Royal Society of Edinburgh 77B, 21-43.

Bradwell, T., Fabel, D., Stoker, M., Mathers, H., McHargue, L. \& Howe, J. (2008). Ice caps existed throughout the Lateglacial Interstadial in northern Scotland. Journal of Quaternary Science 23, 401-407.

Brede, E.G. \& Beebee, T.J.C. (2004). Contrasting population structures in two sympatric anurans: implications for species conservation. Heredity 92, pp.110-117.

Brede, E.G., Rowe, G., Trojanowski, J. \& Beebee, T.J.C. (2001). Polymerase chain reaction primers for microsatellite loci in the common toad Bufo bufo. Molecular Ecology Notes 2, 308-310.

Coles, R.S., Reading, C.J. \& Jehle., R. (2019). Linking effective population size dynamics to phenotypic traits in the common toad (Bufo bufo). Conservation Genetics 20, 987995.

Cottis, R. (2011). Pine marten. In Scott (ed) Atlas of Highland Land Mammals. Inverness: HBRG.

Courchamp, F., Hoffmann, B.D., Russell, J.C., Leclerc, C. \& Bellard, C. (2014). Climate change, sea-level rise, and conservation: keeping island biodiversity afloat. Trends in Ecology \& Evolution 29, 127-130.

Cushman, S.A. (2006). Effects of habitat loss and fragmentation on amphibians: a review and prospectus. Biological Conservation 128, pp.231-240.

Darwin, C.R. (1859) On the Origin of Species. London; Murray

Dolmen, D. \& Seland, J. (2016). How fast do amphibians disperse? Introductions, distribution and dispersal of the common frog (Rana temporaria) and the common toad (Bufo bufo) on a coastal island in Central Norway. Fauna Norvegica 36, 33-46.

Earl, D.A. \& von Holdt, B.M. (2012) STRUCTURE HARVESTER: a website and program for visualizing STRUCTURE output and implementing the Evanno method. Conservation Genet Resour 4, 359-361

Elsom, D. (1988) Catch a falling frog. New Scientist 1615, 129131.

Evanno, G., Regnaut, S. \& Goudet, J. (2005). Detecting the number of clusters of individuals using the software STRUCTURE: a simulation study. Molecular Ecology 14(8), pp.2611-2620.

Evans, W. (1915). Vitrina pellucida adhering to the feathers of a bird and other records of land shells at the Butt of Lewis. Scottish Naturalist (1915), 336. 
Fiegna, C., Clarke, C.L., Shaw, D.J., Baily, J.L., Clare, F.C., Gray, A., Garner, T.W.J. \& Meredith, A.L. (2017). Pathological and phylogenetic characterization of Amphibiothecum sp. infection in an isolated amphibian (Lissotriton helveticus) population on the island of Rum (Scotland). Parasitology 144, 484-496.

Frankham, R. (1997). Do island populations have less genetic variation than mainland populations? Heredity $78, \mathrm{pp} .311$ 327.

Goudet, J. (1995). FSTAT (version 1.2): a computer program to calculate F-statistics. Journal of Heredity 86, 485-486.

Hall, T.A. (1999). BioEdit: a user-friendly biological sequence alignment editor and analysis program for Windows 95/98/ NT. In Nucleic Acids Symposium Series 41, 95-98.

Hewitt, G. (2000). The genetic legacy of the Quaternary ice ages. Nature 405, 907-913.

Hopkins, G.R. \& Brodie, E.D. (2015). Occurrence of amphibians in saline habitats: A review and evolutionary perspective. Herpetological Monographs 29, 1-27.

IPBES, (2019): Global assessment report on biodiversity and ecosystem services of the Intergovernmental SciencePolicy Platform on Biodiversity and Ecosystem Services. E. S. Brondizio, J. Settele, S. Díaz, and H. T. Ngo (editors). IPBES secretariat; Bonn, Germany.

Jakobsson, M. \& Rosenberg, N.A. (2007). CLUMPP: a cluster matching and permutation program for dealing with label switching and multimodality in analysis of population structure. Bioinformatics 23, 1801-1806.

King, K.J., Lewis, D.M., Waters, J.M. \& Wallis, G.P. (2020). Persisting in a glaciated landscape: Pleistocene microrefugia evidenced by the tree wētā Hemideina maori in central South Island, New Zealand. Journal of Biogeography 47, 2518-2531.

Kuraishi, N., Matsui, M. \& Ota, H. (2009). Estimation of the origin of Polypedates leucomystax (Amphibia: Anura: Rhacophoridae) introduced to the Ryukyu Archipelago, Japan. Pacific Science 63, 317-325.

Lambeck, K. (1995). Late Devensian and Holocene shorelines of the British Isles and North Sea from models of glaciohydro-isostatic rebound. Journal of the Geological Society $152,437-448$

Lovas-Kiss, A., Vinczea, O., Lökia, V., Pallér-Kapusia, F., HalasiKovács, B., Kovács, G., Greene, A.J. \& Lukács, B. A. (2020). Experimental evidence of dispersal of invasive cyprinid eggs inside migratory waterfowl. Proceedings of the National Academy of Sciences U.S.A., 117, 15397-15399.

Luquet, E., Léna, J.P., Miaud, C. \& Plénet, S. (2015). Phenotypic divergence of the common toad (Bufo bufo) along an altitudinal gradient: evidence for local adaptation. Heredity 114, pp.69-79.

Marin da Fonte, L. F., Mayer M. \& Lötters, S. (2019). Longdistance dispersal in amphibians. Frontiers of Biogeography 11.4, e44577.

Martinez-Solano, I. \& Gonzalez, E.G. (2008). Patterns of gene flow and source-sink dynamics in high altitude populations of the common toad Bufo bufo (Anura: Bufonidae). Biological Journal of the Linnean Society 95, pp.824-839.

Mayle, F.E., Bell, M., Birks, H.H., Brooks, J., Coope, G.R., Lowe, J.J., Sheldrick, C., Shijie, L., Turney, C.S.M. \& Walker, M.J.C. (1999). Climate variations in Britain, during the last GlacialHolocene transition (15-11.5 cal ka BP): comparison with the GRIP ice-core record. Journal of the Geological Society, London 156, 411-423.

Mclnerny, C. \& Minting, P. (2016). The amphibians \& reptiles of Scotland. Glasgow: Glasgow Natural History Society.

Measey, G.J., Vences, M., Drewes, R.C., Chiari, Y., Melo, M. \& Bourles, B. (2007). Freshwater paths into the ocean: molecular phylogeny of the frog Ptychadena newtoni gives insights into amphibian colonisation of oceanic islands. Journal of Biogeography 34, 7-20.

NBN, (2019). National Biodiversity Network Atlas. https:// nbnatlas.org/ [Accessed 13th July 2019]

New Statistical Account, (1845). Report of the Committee for the Society for the Sons and Daughters of the Clergy superintending the New Statistical Account of Scotland to the General Assembly of the Church of Scotland. Edinburgh: Blackwood.

Oksanen, J., Kindt, R., Simpson, G.L. \& Oksanen, M.J. (2018). Package 'vegan3d.'. R package version, pp.1-0.

Pili, A.N., Sy, E.Y., Diesmos, M.L.L. \& Diesmos, A.C. (2019). Island hopping in a biodiversity hotspot archipelago: Reconstructed invasion history and updated status and distribution of alien frogs in the Philippines. Pacific Science 73, 321-343.

Porras-Hurtado, L., Ruiz, Y., Santos, C., Phillips, C., Carracedo, Á. \& Lareu, M. (2013). An overview of STRUCTURE: applications, parameter settings, and supporting software. Frontiers in Genetics, 4, p.98.

Pritchard, J.K., Stephens, M. \& Donnelly, P. (2000). Inference of population structure using multilocus genotype data. Genetics 155, pp.945-959.

R Core Team, (2018). R: A Language and Environment for Statistical Computing. Version 3.6.2 ed. Vienna, Austria: R Foundation for Statistical Computing.

Recuero, E., Canestrelli, D., Vörös, J., Szabó, K., Poyarkov, N.A., Arntzen, J.W., Crnobrnja-Isailovic, J., Kidov, A.A., Cogălniceanu, D., Caputo, F.P. \& Nascetti, G. (2012). Multilocus species tree analyses resolve the radiation of the widespread Bufo bufo species group (Anura, Bufonidae). Molecular Phylogenetics and Evolution 62, pp.71-86

Reed, D.H. \& Frankham, R. (2003). Correlation between fitness and genetic diversity. Conservation Biology, 17(1), pp.230237.

Rosenberg, N.A. (2004). DISTRUCT: a program for the graphical display of population structure. Molecular Ecology Notes, 4, pp.137-138.

Roth, S. \& Jehle, R. (2016). High genetic diversity of common toad (Bufo bufo) populations under strong natural fragmentation on a Northern archipelago. Ecology and Evolution 6, 1626-1636

Rousset, F. (1997) Genetic differentiation and estimation of gene flow from F-statistics under isolation by distance. Genetics 145, 1219-1228

Rousset, F. (2008). genepop'007: a complete re-implementation of the genepop software for Windows and Linux. Molecular Ecology Resources 8, pp.103-106.

Schiesari, L., Zuanon, J., Azevedo-Ramos, C., Garcia, M., Gordo, M., Messias, M. \& Vieira, E.M. (2003). Macrophyte rafts as dispersal vectors for fishes and amphibians in the lower Solimões River, Central Amazon. Journal of Tropical Ecology 19, 333-336. 
Seppä, P. \& Laurila, A. (1999). Genetic structure of island populations of the anurans Rana temporaria and Bufo bufo. Heredity 82, 309-317.

Shennan, I., Lambeck, K., Flather, R., Horton, B., McArthur, J., Innes, J., Lloyd, J., Rutherford, M. \& Wingfield, R. (2000). Modelling western North Sea palaeogeographies and tidal changes during the Holocene. Geological Society, London, Special Publications 66, 299-319.

Shine, R. (2018). Cane Toad Wars. Berkley: University of California Press.

Sillero, N., Oliveira, M., Sousa, P., Sousa, F. \& GonçalvesSeco, L. (2014). Distributed database system of the New Atlas of Amphibians and Reptiles in Europe: the NA2RE project, Amphibia-Reptilia 35, 33-39.

Taylor, M.S. (1983). The boreal toad (Bufo boreas boreas) as a successional animal in Glacier Bay, Alaska (Doctoral dissertation, Calif State University, Hayward).

Thompson, J.D., Higgins, D.G. \& Gibson, T.J. (1994). CLUSTAL W: improving the sensitivity of progressive multiple sequence alignment through sequence weighting, position-specific gap penalties and weight matrix choice. Nucleic Acids Research 22(22), pp.4673-4680.

Thörn, P., Rödin-Mörch, P., Cortazar-Chinarro, M., Richter-Boix, A., Laurila, A. \& Höglund, J. (2021). The effects of drift and selection on latitudinal genetic variation in Scandinavian common toads (Bufo bufo) following postglacial recolonisation. Heredity, early online.

Thulin, J. \& Andrushaitis, A. (2003). The Baltic Sea: its past, present and future. Religion, science and the environment. Proceedings of the Religion, Science \& the Environment Symposium V on the Baltic Sea, 2003.

Tingley, R., Weeks, A.R., Smart, A.S., van Rooyen, A.R., Woolnough, A.P. \& McCarthy M.A. (2015). European newts establish in Australia, marking the arrival of a new amphibian order. Biological Invasions 17, 31-37.
Tingley, R., García-Díaz, P., Rani, C., Arantes, R. \& Cassey, P. (2017). Integrating transport pressure data and species distribution models to estimate invasion risk for alien stowaways. Ecography 41, 635-646.

Tuncay, S.S., Roth, S., Bardakci, F. \& Jehle, R. (2018). Genetic diversity of common toads (Bufo bufo) along the Norwegian coast: disjunct distribution of locally dominant haplotypes. The Herpetological Journal 28, 127-133.

Vences, M., Vieites, D.R., Glaw, F., Brinkmann, H., Kosuch, J., Veith, M. \& Meyer, A. (2003). Multiple overseas dispersal in amphibians. Proceedings of the Royal Society of London B 270, 2435-2442.

Wallace, A.R. (1880). Island Life. London: Macmillan.

Wang, S., Zhu, W., Gao, X., Li, X., Yan, S., Liu, X., Yang, J., Gao, Z. \& $\mathrm{Li}, \mathrm{Y}$. (2014). Population size and time since island isolation determine genetic diversity loss in insular frog populations. Molecular Ecology 23, 637-648.

Whittaker, R.J. \& Fernández-Palacios, J.M. (2007). Island Biogeography: Ecology, Evolution, and Conservation. Oxford: Oxford University Press.

White, A. W. \& Shine, R. (2009). The extra-limital spread of an invasive species via 'stowaway' dispersal: toad to nowhere? Animal Conservation 12, 38-45.

White, T. A. \& Searle, J. B. (2007). Genetic diversity and population size: Island populations of the common shrew, Sorex araneus. Molecular Ecology 16, 2005-2016.

White, T. A. \& Searle, J. B. (2008). The colonization of Scottish islands by the common shrew, Sorex araneus (Eulipotyphla: Soricidae). Biological Journal of the Linnean Society 94 , 797-808.

Wilkinson, J. W., Beebee, T. J. \& Griffiths, R. A. (2007). Conservation genetics of an island toad: Bufo bufo in Jersey. The Herpetological Journal 17(3), 192-198.

Accepted: 20 July 2021 